\title{
Energy reserves of Artibeus lituratus (Chiroptera: Phyllostomidae) in two areas with different degrees of conservation in Minas Gerais, Brazil
}

\author{
Melo, BES., Barros, MS., Carvalho, TF., Amaral, TS. and Freitas, MB.* \\ Laboratório de Ecofisiologia, Departamento de Biologia Animal - DBA, Universidade Federal de Viçosa - UFV, \\ Av. PH Rolfs, s/n, CEP 36571-000, Viçosa, MG, Brazil \\ *e-mail: mfreitas@ufv.br
}

Received December 17, 2010 - Accepted March 1, 2011 - Distributed February 29, 2012

(With 2 figures)

\begin{abstract}
Forest fragmentation associated with the expansion of human development is a phenomenon that occurs worldwide. Studies reveal that there have been both a decline in species diversity and a decrease in Neotropical bat population size because of habitat loss. The aim of this study was to investigate whether human action has been affecting the food availability to wildlife species, which could impact the storage of body energy reserves. For this purpose, fruit-eating bats (Artibeus lituratus) were collected in two areas in Minas Gerais state, Brazil. The concentrations of plasma glucose, as well as glycogen, lipids and protein in liver in muscles were performed, in addition to adipose tissue weight and carcass fatty acids. Our results indicate that fat reserves were significantly lower in most tested tissues (muscle of the hindlimbs, breast muscles, adipose tissue and carcass) in animals collected in the region with a higher degree of human disturbance. The other parameters showed no significant differences in the groups collected at different locations. In conclusion, we suggest that human action on the environment may be affecting the storage of body fat energy reserves of this species during the autumn, particularly in metropolitan region areas of Belo Horizonte, MG - Brazil, requiring special attention to the species conservation.
\end{abstract}

Keywords: bats, glucose, metabolism, forest fragmentation.

\section{Avaliação das reservas energéticas em Artibeus lituratus (Chiroptera: Phyllostomidae) em áreas com diferentes graus de conservação em Minas Gerais}

\section{Resumo}

A fragmentação florestal associada à expansão do desenvolvimento humano é um fenômeno que ocorre em todo o mundo. Estudos revelam que vêm ocorrendo tanto uma diminuição da diversidade de espécies quanto uma diminuição no tamanho das populações de morcegos neotropicais em função da perda de habitat. Com o objetivo de comparar o armazenamento das reservas energéticas em duas áreas com diferentes graus de conservação, morcegos frugívoros da espécie Artibeus lituratus foram coletados durante o outono de 2009 em duas áreas no Estado de Minas Gerais, Brasil. Foram determinadas as concentrações de glicose plasmática e de glicogênio, proteína e lipídio hepáticos e musculares, além das concentrações lipídicas do tecido adiposo e ácidos graxos totais da carcaça. As reservas lipídicas apresentaram concentrações significativamente menores na maior parte dos tecidos testados (músculo das patas posteriores, músculo peitoral, tecido adiposo e carcaça) nos animais coletados na região menos preservada. Os outros parâmetros não apresentaram diferenças significativas nos grupos coletados nos diferentes locais. Em conclusão, pode-se inferir que a ação humana sobre os ambientes pode estar afetando o armazenamento de reservas energéticas corporais lipídicas de machos dessa espécie, particularmente em áreas da região metropolitana de Belo Horizonte-MG, Brasil, durante o outono.

Palavras-chave: morcegos, glicose, metabolismo, floresta fragmentada. 


\section{Introduction}

Forest fragmentation, associated with human development expansion, is a phenomenon that can occurs worldwide (Viana et al., 1997). The main threats to biodiversity are fragmentation processes, habitat degradation, overexploitation and introduction of exotic species (Primack and Rodrigues, 2001). Depending on the same effects, bats have also presented a decrease in species diversity and population size due to habitat loss (Brosset et al., 1996; Schulze et al., 2000). Several authors show that in bat communities from little changed or with no disturbance forest areas, species diversity is greater than in altered areas (Fenton et al., 1992; Cosson et al., 1999; Medellin et al., 2000; Gorresen and Willig, 2004). In fact, while forests have given way to city advancement, only a few species of bats have shown the capacity to resist to the anthropogenic pressure, whether staying in forest fragments located close to urban environments or settling directly in these ones (Reis et al., 1993; Sazima et al., 1994; Zortéa and Chiarello, 1994; Bredt and Uieda, 1996; Silva et al., 1996; Félix et al., 2001; Esbérard, 2003; Reis et al., 2003). However, which species are best adapted to anthropogenic environments and the corresponding adaptive mechanisms have not been fully elucidated yet.

The energy requirements for the individuals' metabolic functions maintenance comes from diet nutrients, which can provide energy immediately to the body or be stored as carbohydrate reserves (glycogen), lipids and proteins. The storage and mobilisation of these reserves may vary, according to food availability in the environment (Powers et al., 2000; Douglas, 2002). It has been shown that the storage of body energy reserves is essential for the survival and maintenance of several species of bat populations, as the mobilisation of these reserves provides the necessary energy for events associated with reproduction and adaptation to periods of food shortage (seasonality and fasting) (Freitas et al., 2006; Pinheiro et al., 2006; Wang et al., 2008; Freitas et al., 2010).

The relevant role of body energy reserves associated with the maintenance of these populations sizes, associated with the contribution of frugivorous bats to the forest ecosystem conservations - as seed dispersers (Lobava and Mori, 2004), emphasizes the investigation of possible anthropogenic influence in their original habitat on their energy reserve storage, to date little explored in the literature. We hypothesised that bats collected in the urban area would show decreased energy reserves.

To investigate these aspects, the aim of this study was to evaluate plasma glucose levels and the main body energy reserves (glycogen, proteins and fat in the liver and muscle tissues and carcass fatty acids) in the neotropical fruit-eating bat Artibeus lituratus (Olfers, 1818) captured in two areas with different levels of conservation in the state of Minas Gerais, Brazil.

\section{Methods}

\subsection{Study areas}

There were two areas of samples, with different degrees of conservation, both in the state of Minas Gerais, Brazil (Figure 1).

\subsubsection{Area 1 - anthropised area (PUC-MG)}

The Catholic University of Minas Gerais (PUC-MG) is located in the Coraçao Eucarístico neighbourhood, in Belo Horizonte city, Minas Gerais, Brazil (19 ${ }^{\circ} 55^{\prime} \mathrm{S}$ and $43^{\circ} 59^{\prime}$ W). The forest area on the Campus covers an area of approximately 7 ha and an average altitude of $875.0 \mathrm{~m}$ (Ribeiro and Mól, 1985). The annual average rainfall and temperature are $1512 \mathrm{~mm}$ and $21.5^{\circ} \mathrm{C}$, respectively (Werneck, 1998). The local climate reaches the highest temperatures along with the highest rainfall indexes, during October to March, featuring a hot-wet season. The coolest and driest season occurs from April to September (De Knegt et al., 2005).

\subsubsection{Area 2 - preserved area - PERD}

The Rio Doce State Park (PERD) is located among Timóteo, Marliéria and Dionísio towns, at the confluence of the Piracicaba River in the north and Doce River in the south, in Minas Gerais state, Brazil (19²9'- 1948' S and $\left.42^{\circ} 28^{\prime}-42^{\circ} 38^{\prime} \mathrm{W}\right)$. The Park is located in the Atlantic Forest dominium, and its vegetation is characterised as submontante semi- deciduous seasonal forest (Veloso et al., 1991). With 35,974 ha, it is currently the largest area of continuous forest in the state of Minas Gerais, with altitudes ranging from 230-515 m (IGA-MG, 1997). The region of Rio Doce is characterised as one of the three major lake systems that occur in Brazil, together with the Pantanal and the Amazon System (Milkhailova and Barbosa, 2004). The rainy season extends from September to March and the dry season from April to August. The annual average rainfall, temperature and humidity are $1,300 \mathrm{~mm}, 23{ }^{\circ} \mathrm{C}$ and $79 \%$, respectively (CENIBRA, 2003).

\subsection{Animals}

Male and non-pregnant and non-lactating female bats (Artibeus lituratus) were captured in two areas: 1) PUC-MG (5 males and 8 females); and 2) Rio Doce State Park (6 males and 4 females). All animals were collected during the fall of 2009 (March 21 to June 21), in order to avoid seasonal fluctuations of energy reserves.

The animals were captured by using eight mist nets that were opened at low altitude (0-4 m from the ground), during six hours per night after sunset, and inspected at intervals of 20 minutes. The captured specimens were placed individually in cloth bags and transported to the laboratory for methodological procedures. All captures, transportation and experimental procedures were performed according to instructions and authorisation from IBAMA (Process $n^{\circ}$ 18532-1), IEF (UC 008/09) and the Ethics Committee on Animal Use (Process n ${ }^{\circ} 88831 / 2009$ ). The 


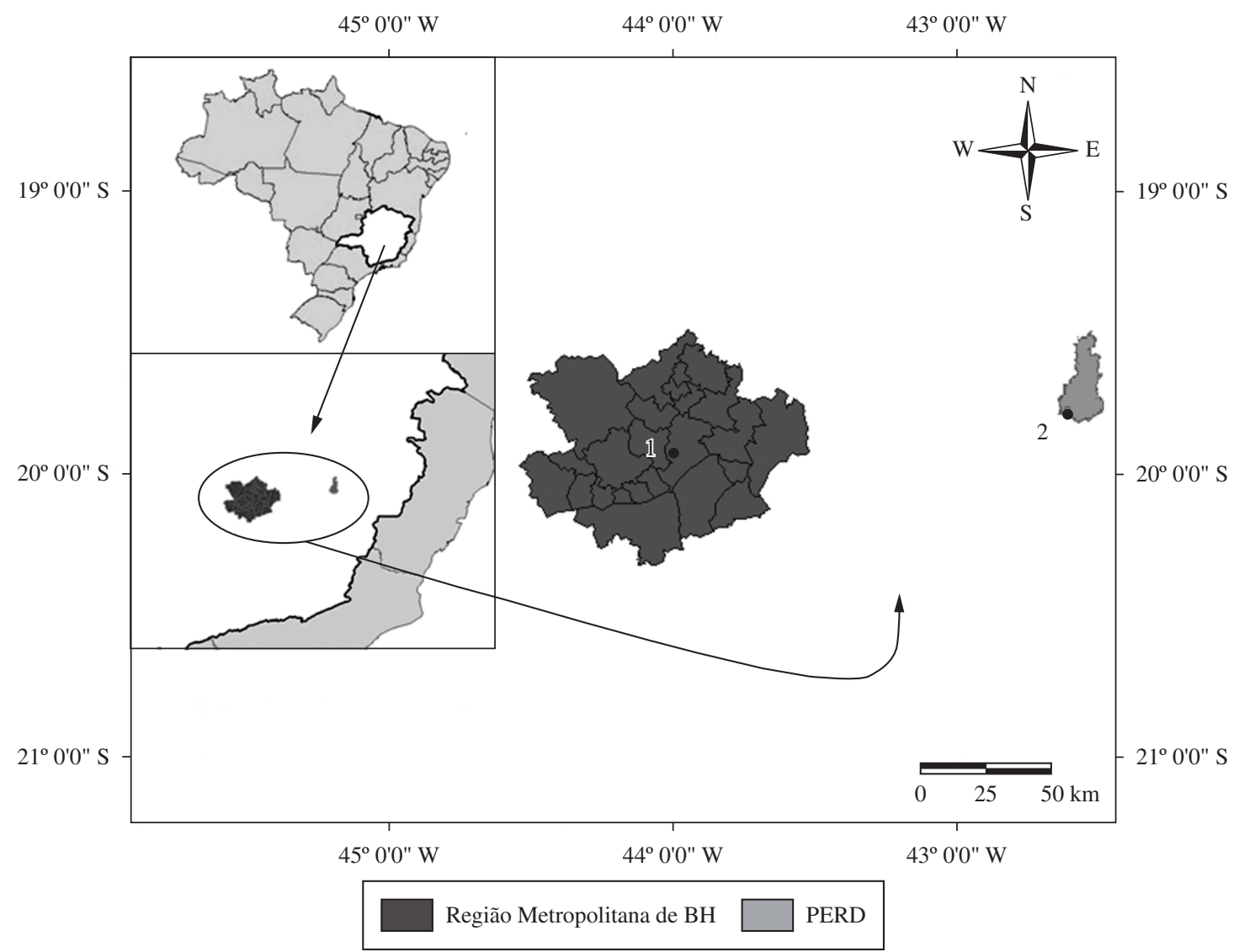

Figure 1. Study areas: 1) PUC-MG (around the city of Belo Horizonte-MG) (19 ${ }^{\circ} 55^{\prime}$ S and $43^{\circ} 59^{\prime}$ W); and 2) PERD (State Park of Rio Doce - PERD-MG) $\left(19^{\circ} 29^{\prime}-19^{\circ} 48^{\prime} \mathrm{S}\right.$ and $\left.42^{\circ} 28^{\prime}-42^{\circ} 38^{\prime} \mathrm{W}\right)$.

animals were classified using a taxonomy key for Brazilian bats according to Vizzoto and Taddei (1973).

\subsection{Sampling}

After net closure, the animals were euthanised by decapitation and their blood was quickly collected into heparinised tubes. The tissues (liver, muscles of the hind limbs and forelimbs, breast and adipose tissue) were removed, weighed and divided into sub-samples, always weighing more than $200 \mathrm{mg}$ per sample, being the exact weight recorded and the tissues then frozen at $-20^{\circ} \mathrm{C}$.

\subsection{Plasma glucose determination}

For plasma glucose determination, the blood was collected in heparinised tubes and immediately centrifuged (2000 rpm/15 minutes) for plasma separation and subsequently stored at $-20{ }^{\circ} \mathrm{C}$. Plasma glucose was determined by the oxidase-glucose enzymatic method GLUCOX 500 (DOLES).

\subsection{Muscle and liver glycogen}

For liver and muscle glycogen determination, tissue samples were placed in conical bottom tubes containing potassium hydroxide $(\mathrm{KOH})$ at $30 \%$ and hydrolysed for 1 hour, being added 5 drops of saturated $\mathrm{Na}_{2} \mathrm{SO}_{4}$.
The tubes containing this solution were centrifuged (2000 rpm/10 minutes), and the supernatant discarded. Glycogen concentration determination was performed by the colorimetric method (Sjörgren et al., 1938).

\subsection{Liver and muscle protein determination}

To determine liver and muscle protein concentration, samples from liver, breast, hindlimb and forelimb muscles were homogenised with $0.9 \%$-saline solution. The colorimetric method was performed through Protein Assay Reagent BCA Kit (PIERCE).

\subsection{Total lipids determination}

For total lipids determination of liver, fat and muscle tissues (breast, hindlimb and forelimb), samples were homogenised with a methanol-chloroform solution (2:1). After filtration and phase separation by addition of saline solution $0.9 \%$, a sample of the chloroform phase $(10 \mathrm{~mL})$ was used for total lipids determination according to Folch et al. (1957).

\subsection{Carcass fatty acids}

After the aforementioned tissues removal, the digestive tract was also removed from the terminal esophagus portion until the anus, kidneys and reproductive organs. The carcass 
was then weighed and digested in $200 \mathrm{~mL}$ of $6 \mathrm{~N} \mathrm{KOH}$ for 4-6 days. After filtering, an equal volume of absolute alcohol was added, resulting in a solution of $\mathrm{KOH}$-ethanol at $50 \%(\mathrm{v} / \mathrm{v})$. A sample of this solution was washed for 3 times with $40 \mathrm{~mL}$ of petroleum ether, acidified with $5 \mathrm{~mL}$ of sulfuric acid $\left(\mathrm{H}_{2} \mathrm{SO}_{4}\right)$ and subjected to extraction with chloroform with three times the final volume. $50 \mathrm{~mL}$ of this phase was used for determination of total fatty acids by the gravimetric method.

\subsection{Statistical analysis}

Data are presented as the Mean \pm Standard Error of Mean (SEM). For comparisons between groups, the students' $t$-test was used. For non-parametric data, the Mann-Whitney test was performed. The criterion of significance was set at $5 \%(P<0.05)$.

\section{Results}

Because gender showed no significant influence on the results of any of the variables tested, data obtained from male and female bats were pooled.

There was no statistical difference in plasma glucose concentrations from bats collected at PUC-MG $\left(6.68 \pm 1.14 \mathrm{mmol} . \mathrm{L}^{-1}\right)$ and PERD $\left(5.65 \pm 0.76 \mathrm{mmol} . \mathrm{L}^{-1}\right)$ (Figure 2).

In the same way as for plasma glucose, there was no significant difference in muscle or liver glycogen concentrations in animals collected in both areas (Table 1). Total protein concentrations also showed no statistical variation between animals from both groups, except for forelimb muscles, increased PUC-MG animals (Table 1). Considering fat reserves, total lipids from hindlimb muscles, breast muscles and adipose tissue, as well as carcass fatty acids showed decreased values in animals collected at PUC-MG, the urban area, compared to those from the preserved forest in PERD. Forelimb and liver values showed statistically similar values (Table 1 ).

\section{Discussion}

To our knowledge, this is the first study to evaluate the energy reserves storage in neotropical fruit-eating bats from areas of different conservation status. Food availability in the environment, essential for energy reserve accumulation in wild animals, has been reported as threatened by human action, as decreased amount and diversity of plant species in small forest fragments or in disturbed areas are continually being reported (Fonseca and Robinson, 1990; Galindo-Leal and Câmara, 2003). Energy reserves storage is thought to be an important issue for wild species survival, especially in times of seasonal food shortages and/or during reproductive events (Moreno et al., 1993).

Our results have demonstrated that plasma glucose concentrations of $A$. lituratus are similar from those reported for this species (Pinheiro et al., 2006) and other bat species (Freitas et al., 2003), and showed no significant differences between animals captured in different areas.

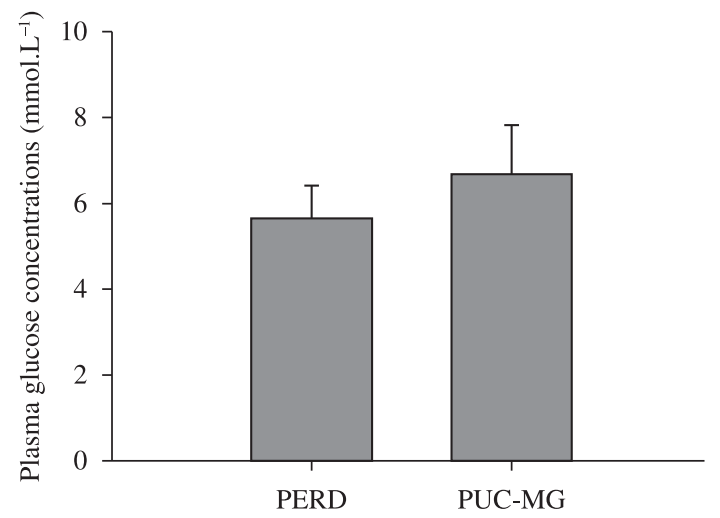

Figure 2. Plasma glucose concentrations $\left(m m o l . L^{-1}\right)$ in Artibeus lituratus colleted at PERD and PUC-MG. Values are means \pm SEM.

Table 1. Concentrations of glycogen, protein and lipids in several tissues of fruit-eating bats (Artibeus lituratus) collected in two areas in Minas Gerais State, Brazil.

\begin{tabular}{lcc}
\hline \multicolumn{1}{c}{ Tissues } & PERD & PUC-MG \\
\hline Liver glycogen $\left(\mu . \mathrm{mol}^{-1}\right.$ glucosil-units/g) & $22.01 \pm 5.79$ & $21.89 \pm 4.47$ \\
Breast muscle glycogen $\left(\mu . \mathrm{mol}^{-1}\right.$ glucosil-units/g) & $33.64 \pm 9.49$ & $45.29 \pm 19.30$ \\
Liver protein $\left(\mathrm{g} .100 \mathrm{~g}^{-1}\right)$ & $16.94 \pm 0.55$ & $18.40 \pm 1.57$ \\
Breast muscle protein $\left(\mathrm{g} .100 \mathrm{~g}^{-1}\right)$ & $9.47 \pm 0.75$ & $9.65 \pm 0.65$ \\
Forelimb muscle protein $\left(\mathrm{g} .100 \mathrm{~g}^{-1}\right)$ & $11.36 \pm 0.62$ & $14.15 \pm 0.73^{*}$ \\
Hindlimb muscle protein $\left(\mathrm{g} .100 \mathrm{~g}^{-1}\right)$ & $9.60 \pm 0.51$ & $11.03 \pm 0.69$ \\
Liver lipids $\left(\mathrm{g} .100 \mathrm{~g}^{-1}\right)$ & $7.33 \pm 0.50$ & $6.56 \pm 0.37$ \\
Breast muscle lipids $\left(\mathrm{g} .100 \mathrm{~g}^{-1}\right)$ & $7.04 \pm 0.60$ & $5.51 \pm 0.29^{*}$ \\
Forelimb muscle lipids $\left(\mathrm{g} .100 \mathrm{~g}^{-1}\right)$ & $4.96 \pm 0.31$ & $4.39 \pm 0.13$ \\
Hindlimb muscle lipids $\left(\mathrm{g} .100 \mathrm{~g}^{-1}\right)$ & $5.80 \pm 0.55$ & $3.70 \pm 0.29^{*}$ \\
Carcass fatty acids $\left(\mathrm{g} .100 \mathrm{~g}^{-1}\right)$ & $4.05 \pm 0.46$ & $2.27 \pm 0.11^{*}$ \\
Adipose tissue lipids $\left(\mathrm{g} .100 \mathrm{~g}^{-1}\right)$ & $41.12 \pm 6.48$ & $18.05 \pm 2.26^{*}$ \\
\hline
\end{tabular}

PERD = Parque Estadual do Rio Doce; PUC-MG = Pontifícia Universidade Católica de Minas Gerais. 
Careful maintenance of constant blood glucose levels involves several mechanisms responsible for the use of nutrients from the diet or stored energy as a body fuel reserve (Genuth, 1998; Weber, 2001). Frugivorous bats, such as Artibeus lituratus, may ingest the equivalent of its body weight every night, and are known to digest its carbohydrate-rich meals rapidly and efficiently (Craik and Markovich, 2000). This species feed on a variety of fruits, with preference for those from the genus Ficus (Morrison, 1978).

Liver and muscle glycogen concentrations have shown no significant difference among sampling sites, suggesting that these reserves are not being directly affected by the conservation degree of the environment.

Similarly, protein reserves of the analysed tissues showed no significant differences between the two areas, except for protein concentration in the forelimbs, which was significantly higher in animals collected at PUCMG. One possible explanation for this topic result is the possibility of a supplementary insect feeding in this group, induced possibly by the reduced availability of fruit items at PUC-MG compared to the preserved area of the park. Several authors have reported that, despite A. lituratus presenting a predominantly frugivorous diet (Fleming, 1986; Galetti and Morellato, 1994; Zortéa and Chiarello, 1994; Passos et al., 2003), it may assume a more generalist diet in regions where plant density is low (Galetti and Morellato, 1994). This particular feature could be seen as indicative of a wide feeding flexibility, allowing adaptations to different situations of food supply, since observations of food consumption during food abundance shows a clear preference for fruit from the families Cecropiaceae and Moraceae (Fleming, 1986; Passos et al., 2003). However, when fruits are scarce, animals end up using a more generalist feeding strategy, eating a variety of available species, including protein sources like insects (Passos and Graciolli, 2004).

Regarding lipid reserves, fat reserves were decreased in four tissues from animals collected in the anthropised area (PUC-MG), suggesting that lipid reserves were more evidently influenced by human action. One possible reason for decreased values found for fat reserves is a lower carbohydrate ingestion (fruit items) by animals from the anthropised area of PUC-MG compared to the preserved area of PERD, which reduces lipogenesis (Kettelhut et al., 1980; Botion et al., 1992). Nevertheless, further studies on this species feeding ecology are necessary to verify the diet composition at the two of study sites.

Lipids play an important role in the processes of energy production and as a source of essential fatty acids (Pezzato, 1995). Bats exhibit a wide range of thermo-regulatory patterns, which may vary depending on the type of diet and nutritional status. Some of the species of this taxon do not have mechanisms to control body temperature as efficiently as other warm-blooded mammals (McNab, 1973; Speakman and Thomas, 2003). Therefore, it is possible that the fat reserves in carcass play an important role in maintaining this endothermic species. Concerning the role of fat reserves during reproduction events, such as hormone and sperm production, pregnancy and lactation, it is reported increases of adipose depots prior to these events, mainly in retroperitoneal, parametrial and sub-scapular areas (Moore et al., 1984). This fact is due to increased metabolic demands for sustained fetal growth or mammary gland development, for example (Moore et al., 1984).

Considering the role of lipid stores on reproduction, decreased fat reserves observed in animals captured in the anthropised area may cause complications for energy supply and a proper development of the reproductive activities, especially considering seasonal variations of food availability and the long gestation of four months estimated for this bat species (Reis, 1989). In a long-term evaluation, decreased fat reserves could eventually affect bat populations.

In conclusion, our results suggest that there are differences in the body energy reserves storage between areas with different degrees of conservation, with decreased fat reserves in fruit-eating bats Artibeus lituratus living in metropolitan areas of southeastern Brazil.

Acknowledgements - This study was supported by FAPEMIG (grant to B. Melo). We are grateful to the Parque Estadual do Rio Doce (PERD) for field assistance and to PUC-MG for allowing the use of the laboratory during captures at this site. We also thank Unileste - MG for the use of their laboratory.

\section{References}

BOTION, LM., KETTELHUT, IC. and MIGLIORINI, RH., 1992. Reduced lipogenesis in rats fed a high-protein, carbohydrate-free diet: participation of liver and four adipose depots. Brazilian Journal of Medical and Biological Research, vol. 25, no. 4, p. 419-428.

BREDT, A. and UIEDA, W., 1996. Bats from urban and rural environments of the Distrito Federal, mid-western Brazil. Chiroptera Neotropical, vol. 2, no. 2, p. 54-57.

BROSSET, A., CHARLES-DOMINIQUE, P., COCKLE, A., COSSON, JF. and MASSON, D., 1996. Bat communities and deforestation in French Guiana. Canadian Journal of Zoology, vol. 74, p. 1974-1982. http://dx.doi.org/10.1139/z96-224

CENIBRA, 2003. Dados meteorológicos da estação de Belo Oriente. Belo Oriente.

COSSON, JF., PONS, JM. and MASSON, D., 1999. Effects of forest fragmentation on frugivorous and nectarivorous bats in French Guiana. Journal of Tropical Ecology, vol. 15, p. 515-534. http://dx.doi.org/10.1017/S026646749900098X

CRAIK, JD. and MARKOVICH, D., 2000. Rapid GLUT-1 mediated glucose transport in erythrocytes from the grey-headed fruit bat (Pteropus poliocephalus). Comparative Biochemistry and Physiology, vol. 126A, no. 1, p. 45-55.

De KNEGT, LV., SILVA, JA., MOREIRA, EC. and SALES, GL., 2005. Morcegos capturados no município de Belo Horizonte. Arquivo Brasileiro de Medicina Veterinária e Zootecnia, vol. 57, p. 576-583.

DOUGLAS, CR., 2002. Tratado de Fisiologia Aplicada a Nutrição. 5nd ed. Robe. 1046 p. 
ESBÉRARD, CEL., 2003. Diversidade de morcegos em área de Mata Atlântica regenerada no sudeste do Brasil. Revista Brasileira de Zoociências, vol. 5, no. 2, p.189-204.

FÉLIX, JS., REIS, NR., LIMA, IP., COSTA, EF. and PERACCHI, AL., 2001. Is the area of the Arthur Thomas park, with 82.72 ha, sufficient to maintain viable chiropteran populations? Chiroptera Neotropical, vol. 7, no. 1-2, p. 129-133.

FENTON, MB., ACHARYA, L., AUDET, D., HICKEY, MBC., MERRIMAN, C., OBRIST, MK., SYME, DM. and ADKINS, B., 1992. Phyllostomid bats (Chiroptera: Phyllostomidae) as indicators of habitat disruption in the Neotropics. Biotropica, vol. 24, no. 3, p. 440-446.

FLEMING, TH., 1986. Opportunism versus specialization: evolution of feeding strategies in frugivorous bats. In: ESTRADA, A. and FLEMING, TH. Frugivores and seed dispersal. Dordrecht: W. Junk Puplisher. p. 105-118. http://dx.doi.org/10.1007/978-94009-4812-9_11

FREITAS, MB., GOULART, LS., BARROS, MS., MORAIS, DB., AMARAL, TS. and MATTA, SL., 2010. Energy metabolism and fasting in male and female insectivorous bats Molossus molossus (Chiprotera: Molossidae). Brazilian Journal of Biology, vol. 70, no. 3, p. 617-621. http://dx.doi.org/10.1590/S151969842010000300019

FREITAS, MB., WELKER, AF., MILLAN, SF. and PINHEIRO, EC., 2003. Metabolic responses induced by fasting in the common vampire bat Desmodus rotundus. Comparative Biochemistry and Physiology, vol. 173B, no. 8, p. 703-707.

FREITAS, MB., WELKER, AF. and PINHEIRO, EC., 2006. Seasonal variation and food deprivation in common vampire bats (Chiroptera: Phyllostomidae). Brazilian Journal of Biology, vol. 66 , no. 4 , p. 1051-1055.

FOLCH, J., LESS, M. and SLORNE STANLEY GH., 1957. A simple method for the isolation and purification of total lipids from animal tissues. Journal of Biological Chemistry, vol. 497, p. 26.

FONSECA, GAB. and ROBINSON, JG. Forest size and structure: competitive and predatory effects on small mammal communities., 1990. Conservation Biology, vol. 53, p. 265-294. http://dx.doi.org/10.1016/0006-3207(90)90097-9

GALETTI, M. and MORELLATO, LPC., 1994. Diet of the large fruit-eating bat Artibeus lituratus in a forest fragment in Brazil. Journal of Mammalogy, vol. 58, no. 4, p. 661-665.

GALINDO-LEAL, C. and CÂMARA, IG., 2003. The Atlantic forest of South America: biodiversity status, threats, and outlook. Whashington: Island Press

GENUTH, S., 1998. For aggressive preventive management of type 2 diabetes. What is the evidence and is it enough? Journal of Family Practice, vol. 47, no. 5, p. S23-26.

GORRESEN, PM., WILLIG, MR., 2004. Landscape responses of bats to habitat fragmentation in Atlantic Forest of Paraguay. Journal of Mammalogy, vol. 85, no. 4, p. 688- 697. http://dx.doi. org/10.1644/BWG-125

Instituto de Geociências Aplicadas de Minas Gerais - IGAMG, 1997. Mapa geomorfológico 1:500.000. Belo Horizonte: Secretaria de Estado de Ciência e Tecnologia de Minas Gerais. Projeto RADAR-MG.

KETTELHUT, IC., FOSS, MC. and MIGLIORINI, RH., 1980. Glucose homeostasis in a carnivorous animal (cat) and in rats fed a high protein diet. American Journal of Physiology, vol. 239, no. 5, p. R437-R444.

LOBAVA, TA. and MORI, SA., 2004. Epizoochorous dispersal by bats in French Guiana. Short communication. Journal of Tropical Ecology, vol. 20, p.581-582. http://dx.doi.org/10.1017/ S0266467404001634

McNAB, BK., 1973. Energetics and the distribution of vampires. Journal of Mammalogy, vol. 54, no. 1, p. 131-144. http://dx.doi. org/10.2307/1378876

MEDELLIN, RA., EQUIHUA, M. and AMIN, MA., 2000. Bat diversity and abundance as indicators of disturbance in Neotropical rainforests. Conservation Biology, vol. 14, no. 6, p. 1666-1675. http://dx.doi.org/10.1046/j.1523-1739.2000.99068.x

MILKHAILOVA, I. and BARBOSA, FR., 2004. Estimativa preliminar do valor de recursos ambientais do Parque estadual do Rio Doce (MG): Uma aplicação dos métodos "Disposição a Pagar". Available from: <www.cemac.ufla.com.br>.

MOORE, BJ., OLSEN, JL., MARKS, F. and BRASEL, JA., 1984. The effects of high fat feeding during one cycle of reproduction consisting of pregnancy, lactation and recovery on body composition and fat pad cellularity in the rat. Journal of Nutrition, vol. 114, p. $1566-1573$.

MORENO, FJ., ALONSO, G. and ROS, M., 1993. Bromocryptine treatment increases lipolysis and steady-steady levels of $\mathrm{G}$ proteins in adipocytes from lactating rats. Biochimica et Biophysica Acta, vol. 1222 , p. 203-207.

MORRISON, DW., 1978. Foraging ecology and energetic of the frugivorous bat Artibeus jamaicensis. Ecology, vol. 59, p. 716723. http://dx.doi.org/10.2307/1938775

PASSOS, FC. and G. GRACIOLLI., 2004. Observações sobre a dieta de Artibeus lituratus (Chiroptera, Phyllostomidae) em duas áreas do sul do Brasil. Revista Brasileira de Zoologia, vol. 21, no. 3 , p. 487-489.

PASSOS, FC., SILVA, WR., PEDRO, WA. and BONIN, MR., 2003. Frugivoria em Morcegos (Chiroptera, Phyllostomidae) no Parque Estadual Intervales, sudeste do Brasil. Revista Brasileira de Zoologia, vol. 20, no. 3, p. 511-517.

PEZZATO, LE., 1995. Alimentos convencionais e não convencionais disponíveis para a indústria de nutrição de peixes no Brasil. In: Anais do Simpósio internacional sobre nutrição de peixes e crustáceos, 1995. Campos do Jordão: CBNA. p. 35-52.

PINHEIRO, EC., TADDEI, VA., MIGLIORINI, RH. and KETTELHUT, IC., 2006. Effect of fasting on carbohydrate metabolism in frugivorous bats (Artibeus lituratus and Artibeus jamaicensis). Comparative Biochemistry and Physiology, vol. 143B, no. 3 , p. 279-284.

POWERS, SK. and HOWLEY, ET., 2000. Mensuração do Trabalho, da Potência e do Gasto Energético. In: POWERS, SK. and HOWLEY, ET. Fisiologia do Exercício: Teoria e Aplicação ao Condicionamento e ao Desempenho. 3nd ed. São Paulo: Ed Manole. 527 p.

PRIMACK, RB. and RODRIGUES, E., 2001. Biologia da conservação. Londrina: Ed. Vozes. 328 p

REIS, NR., BARBIERI, MLS., LIMA, IP. and PERACCHI, AL., 2003. O que é melhor para manter a riqueza de espécies de morcegos (Mammalia, Chiroptera): um fragmento florestal grande ou vários fragmentos de pequeno tamanho? Revista Brasileira de Zoologia, vol. 20, no. 2, p. 225-230. 
REIS, NR., PERACCHI, AL. and ONUKI, MK., 1993. Quirópteros de Londrina, Paraná, Brasil (Mammalia, Chiroptera). Revista Brasileira de Zoologia, vol. 10, no. 3, p. 371-381.

REIS, SF., 1989. Biologia reprodutiva de Artibeus lituratus (Olfers, 1818) (Chiroptera: Phyllostomidae). Revista Brasileira de Biologia = Brazilian Journal of Biology, vol. 49, no. 2, p. 369-372.

RIBEIRO, C. and MÓL, CRF., 1995. Avaliação das mudanças climáticas em Belo Horizonte: Análise dos parâmetros de temperatura e precipitação. In: Anais do Simpósio da situação ambiental e qualidade de vida na região metropolitana de Belo Horizonte, MG, 1995. Belo Horizonte: ABEG.

SAZIMA, I., FISCHER, WA., SAZIMA, M. and FISCHER, EA., 1994. The fruit bat Artibeus lituratus as a forest and city dweller. Ciência e Cultura, vol. 6, no. 3, p. 164-168.

SCHULZE, MD., SEAVY, NE. and WHITACRE, DF., 2000. A comparison of phyllostomid bat assemblages in undisturbed Neotropical forest and in forest fragments of a slash and burn farming mosaic in Petén, Guatemala. Biotropica, vol. 32, p. 174-184.

SILVA, MMS., HARMANI, NMS., GONÇALVES, EFB. and UIEDA, W., 1996. Bats from the metropolitan region of São Paulo, southeastern Brazil. Chiroptera Neotropical, vol. 2, no. 1, p. 39-41.

SJÖRGREN, B., NOERDENSKJÖLD, T., HOLMGREN, H. and MÖLLERSTROM, J., 1938. Beitrag zur Kenntnis der Leberrhythmik (glykogen, Phosphor und Calcium in der Kaninchenleber). Pflügers Archiv - European Journal of Physiology, vol. 240, no. 4, p. 427-448.

SPEAKMAN, JR. and THOMAS, DW., 2003. Energetics and physiological ecology of bats. In: KUNZ, TH. and FENTON, MB. Bat Ecology. The University of Chicago Press. 779 p.
VELOSO, HP., RANGEL FILHO, ALR. and LIMA, JCA., 1991. Classificação da vegetação brasileira, adaptada a um sistema universal. Rio de Janeiro: IBGE, Departamento de Recursos Naturais e Estudos Ambientais. 124 p.

VIANA, VM., TABANEZ, AAJ. and BATISTA, JLF., 1997. Dynamics and restoration of forest fragments in the Brazilian Atlantic Moist Forest. In Laurance, WF., Bierregaard JUNIOR, RO., (Eds). Tropical forest remnants: ecology, management and conservation of fragmented communities. The University of Chicago Press. 632 p.

WANG, MC., O'ROURKE, EJ. and RUVKUN, G., 2008. Fat metabolism links germline stem cells and longevity in C. elegans. Science, vol. 322, no. 5903, p. 957-960. http://dx.doi.org/10.1126/ science. 1162011

WEBER, JM., 2001. Energy cycle in Vertebrates. In Encyclopedia of Life Sciences. London: Nature Publishing Group.

WERNECK, MS., 1998. Comparação entre dois métodos para análise florística e estrutura de um trecho de floresta mesófila da mata da PUC Minas, Belo Horizonte - MG. Bios, vol. 6, no. 6, p. 21-31.

ZORTÉA, M. and CHIARELLO, AG., 1994. Observations on the big fruit-eating bat, Artibeus lituratus, in a urban reserve of southeast Brazil. Journal of Mammalogy, vol. 58, no. 4, p. 665-670.

VIZZOTO, LD. and TADDEI, VA., 1973. Chave para determinação de quirópteros brasileiros. Revista da Faculdade de Filosofia e ciências e Letras de São José do Rio Preto, vol. 1, p. 1-72. 
